\title{
Bildrik populärvetenskap om dansk-judisk historia
}

\author{
BOKRECENSION
}

Cecilie Felicia Stokholm Banke, Signe Bergman Larsen, Janne Laursen, Martin Schwarz Lausten, Hanne Trautner-Kromann, En indvandringshistorie. Jøder i Danmark 400 år (Dansk Jødisk Museum, 2018). English version: A Story of Immigration. Four Hundred Years of Jews in Denmark, trans. Virginia Laursen and Fran Hopenwasser (The Danish Jewish Museum, 2018).

Detta är en populär framställning av danskjudisk historia under 400 år, utan fotnoter eller vetenskapliga ambitioner. Ungefär hälften av framställningen utgörs av bilder och layouten är luftig och tilltalande. Boken finns både i en dansk och i en engelsk version.

Boken är tematiskt disponerad, välbalanserad och vederhäftigt skriven av ett författarkollektiv på fem personer, alla kompetenta inom sina respektive specialiteter. Boken är självklart, som påpekas, inte heltäckande, och mycket forskning väntar på att bli utförd.

Att räddningen hösten 1943 av nästan alla danska judar till Sverige är världsberömd framhålls i förordet, men syftet med denna bok är att lyfta fram hela den dansk-judiska historien. Att mycket av det som skrivits om denna handlar om ockupationsåren framgår också väl av att ungefär hälften av de 49 titlarna i litteraturlistan har detta tema. Författarna lyckas här väl i sin föresats att ha en bredare framställning: krigsåren ägnas ungefär en sjättedel av utrymmet.

I ett inledningskapitel behandlas kronologiskt den judiska invandringen till Danmark som på många sätt skiljer sig från den i de andra nordiska länderna. Redan på I620- och

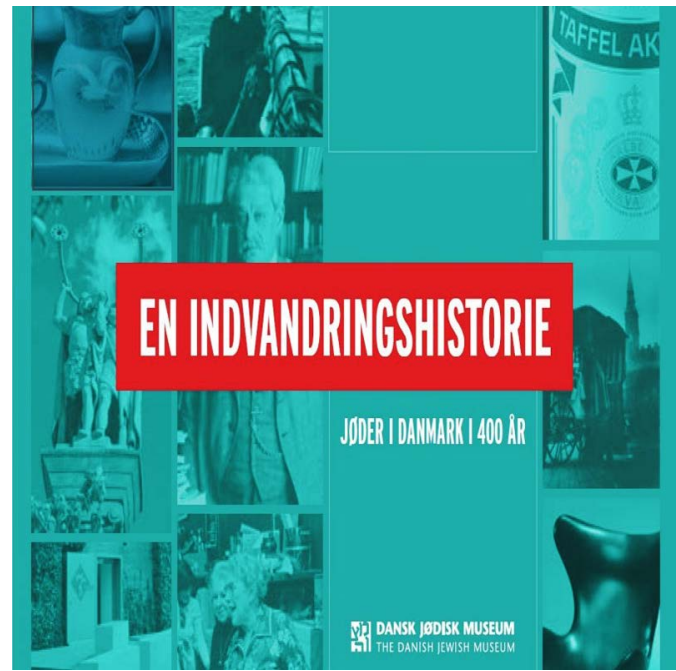

I630-talen kom 30 sefardiska familjer från Hamburg, Amsterdam och andra platser till staden Glückstadt i Holstein, ett hertigdöme under danske kungen men med egen administration. Kungen, Kristian IV, hade nyligen anlagt staden med syfte att konkurrera med det närbelägna Hamburg och han stimulerade judar att flytta dit eftersom de ansågs kunna få fart på handelsverksamheten. Liknande förslag vid samma tid i Sverige gick inte igenom på grund av den starka religiösa fientligheten mot judar. I Altona som r640 blev införlivat i Holstein bodde ytterligare många sefarder, och flera av dem kom senare att flytta norrut till det danska kungariket.

När fästningsstaden Fredericia, som låg i kungariket, $\mathrm{I} 674$ gavs privilegier och religionsfrihet, utnyttjades detta av flera judar. Under 
I 70o-talet fick flera judar tillstånd att bosätta sig i flera andra danska städer, även om de aldrig var särskilt många. Ännu vid mitten av I80otalet bodde 40 procent utanför Köpenhamn, men senare under seklet blev det en mycket stark koncentration till huvudstaden. Detta berodde inte minst på den stora östjudiska invandringen decennierna kring sekelskiftet I900. Köpenhamn var en viktig hamnstad och det uppges att cirka ı० ০oo-I 2000 ryska judar anlände, varav omkring 3000 stannade och resten reste vidare.

I likhet med Sverige blev det vissa spänningar med de gamla och välintegrerade judarna, som i regel hade annan religiös, kulturell och socioekonomisk tillhörighet; många tillhörde nu en dansk elit. De jublade inte direkt över de nyinvandrade, även om de också bistod med ekonomisk hjälp.

Många av invandrarna bodde koncentrerat, men att, som görs, säga att detta hade karaktären av ett judiskt getto är enligt min uppfattning att relativisera detta begrepp. Många arbetade inom textilindustrin, många arbetade hemma, många var socialister och medlemmar av Bund, och många var sionister. De integrerade sig i regel så småningom ganska väl i det danska samhället, barnen lärde sig danska ganska snabbt även om det också fanns en levande jiddischkultur.

På r 930-talet kom, trots restriktiv invandringspolitik, cirka 4000 flyktingar till landet. Nästa stora invandring kom mellan I 969 och I 973 då cirka 3000 judar invandrade som en reaktion på de hätska antisemitiska kampanjerna i Polen.

Ett kapitel i boken handlar om ramarna för judiskt liv. Religiösa och andra föremål såsom chanukkaljusstakar, torarullar och insamlingsbössor visas och förklaras. De sex synagogor som en gång fanns i landsorten presenteras kortfattat med fotografier: Faaborg, Naksov, Fredericia, Horsens, Aalborg och Randers. Församlingen i den senare staden lades ner 1936 som den sista av dessa provinsförsamlingar.
Efter att synagogan i Köpenhamn brunnit 1795 blev det en stor religiös splittring och minst tolv olika bönehus uppstod. Överrabbinen Abraham Alexander Wolff lyckades ganska väl skapa enighet några decennier senare, och den stora synagogan på Kristallgade invigdes r 833 . Ett par traditionellt ortodoxa församlingar uppstod dock, och i dag finns även Chabad och Shir Hatzafan representerade, den sista inspirerad av Progressive Judaism.

Ett ganska kort kapitel handlar om relationen till den danska kyrkan och ett längre om relationen till stat och samhälle i stort. Den religiösa antijudaismen var djupt rotad. Det danska prästerskapet kunde inte stoppa Kristian IV:s invandringsprojekt, men hade ändå stort inflytande på synen på judar. Införandet av religionsfriheten I 849 till trots, kunde exempelvis till och med den inflytelserike teologen, författaren med mera N.F.S. Grundtvig, annars tolerant, hävda att författaren Meïr Aron Goldschmidt inte var helt dansk. Trots att denne var född i Danmark och behärskade det danska språket perfekt betraktades han som en främmande gäst.

När det gäller integration, religiös reformation, legala rättigheter och liknande påminner mycket om utvecklingen i Sverige. I Danmark låg man dock hela tiden före. Den så kallade Anordningen från I 8 I 4 som reglerade mosaiska trosbekännares närvaro i Danmark (dock inte i hertigdömena) likställde - åtminstone nästan - judar med övriga danskar. Beteckningen "judisk" ändrades nu till "mosaisk" - drygt 20 år före motsvarande förändring i Sverige. Den parallella religiösa reformprocessen kom också att starta betydligt tidigare än i Sverige; reformivriga Göteborgsjudar kom också att rådfråga den danske överrabbinen Wolff.

Integrationen ledde bland annat till att många judar intog framträdande roller inom exempelvis textilindustrin. Tobaksfabrikören Heinrich Hirschsprung donerade 1902 sin konstsamling till den danska staten; samlingen utgör i dag ett välkänt museum. Många andra 
starka danska varumärken har en gång grundats av judar. En av stiftarna till porslinsfabriken Bing \& Gröndahl tillhörde en danskjudisk familj, liksom en av grundarna till Tuborgs bryggeri. Att den som en gång introducerade Aalborgs akvavit var en invandrad dansk jude är det kanske inte många som känner till.

Ett kort kapitel behandlar den mer ras- eller kulturmässiga antisemitismen i Danmark från mitten av I 80o-talet och framåt med exempel på antisemitiska organisationer, skämtteckningar och publikationer. Även i Danmark utgavs en översättning av Zions Vises Protokoller, som fortsatte att komma ut i flera upplagor trots att "protokollen" avslöjades som förfalskade. Även om nazismen i Danmark var marginell och antisemitism inte tillhörde "god ton" var det uppenbart att sådan existerade påpekas det. När Marcus Melchior, senare överrabbin, flyttade tillbaka r933 till Danmark från Tyskland och började hålla antinazistiska föredrag, ombads han av församlingsföreståndaren att sluta med detta eftersom strategin var att ligga lågt och inte kritisera Nazityskland. Melchior ville dock lyfta upp de antisemitiska metoderna och gav I 936 ut boken Man siger at joderne.

Efterkrigstidens antisemitism, ofta med kopplingar till konflikter i Mellanöstern tas också upp. År I 985 utsattes såväl synagogan som en kosherbutik för bombattentat, och i februari 20I 5 försökte en radikaliserad islamist förgäves bryta sig in i synagogan och dödade i samband med detta en ung judisk man som satt utanför som frivillig vakt. Denna terrorhandling utlöste en chock i det danska samhället. En stor bild i boken visar det stora blomsterhav som danskar lade utanför synagogan efter dådet som en sympatiyttring.

Även om boken som sagt inte alltför mycket velat fokusera på krigsupplevelserna, har dessa givetvis sin plats och sammanfattas kortfattat. Läsaren får en översiktlig beskrivning av allt ifrån ockupationens inledning den 9 april I940, via undantagstillståndet och razziorna i början av hösten I943, hur marinattachén Duckwitz läckte om den planerade deportationen, rabbinen Melchiors morgongudstjänst och själva flykten över Öresund i början av oktober. Räddningen av de danska judarna utgör en välkänd "solskenshistoria" - ett undantag i berättelsen om Förintelsen.

Det påpekas att inte bara danska motståndsmän deltog i räddningen, utan även grupper som tidigare aldrig utfört illegala aktioner. Fiskare och skeppare tog stora risker och tog betalt för sina tjänster, men att den som inte hade råd fick hjälp av hjälporganisationen eller andra flyktingar framhålls. Det genomsnittliga priset uppgavs vara cirka I ooo kronor per person, motsvarande ungefär två och en halv månadslön för en yrkesutbildad arbetare. Bland fotografierna finns det enda kända autentiska från flykten, taget ombord på en fiskebåt från Falster på väg mot Ystad.

Mottagandet i Sverige behandlas också, liksom vad som hände med de 470 danska judar som av olika skäl inte flydde utan hamnade $\mathrm{i}$ koncentrationslägret i Theresienstadt utanför Prag. Även om förhållandena var fruktansvärda med hårt arbete och dålig kost fick de en bättre behandling än andra fångar vilket medförde att nästan 90 procent överlevde, om än med hemska upplevelser som de sedan var tvungna att fortsätta att leva med. De flesta av de 53 danska judar som dog i lägret gjorde det i början av vistelsen och till följd av utmattning, svält och hårt arbete.

Den I5 april r 945 blev de danska judarna upphämtade av de Vita bussarna. I början av maj kapitulerade de tyska trupperna i Danmark och så småningom kunde de danska judarna åka tillbaka till sitt land. Närmare 2 ooo judar hade inget hem längre, utan fick bo i tillfälliga läger $\mathrm{i}$ väntan på bostad.

Sammanfattningsvis kan sägas att boken mycket väl lever upp till sina intentioner. Informationen är koncis och balanserad. Den kommer säkert att fungera som en bra 
introduktion om dansk-judisk historia för museibesökare och andra intresserade. Förhoppningsvis blir det också en aptitretare för ytterligare fördjupning.

\section{CARL HENRIK CARLSSON}

Carl Henrik Carlsson är filosofie doktor i historia, verksam som forskare vid Hugo Valentin-centrum, Historiska institutionen, Uppsala universitet, och som redaktör vid Riksarkivet. Har skrivit en lång rad böcker och artiklar om svensk-judisk historia och undervisar i detta ämne på Uppsala universitet och Paideia folkhögskolai Stockholm. Han är koordinator för forskarnätverket "Judarna i Sverige - en minoritets historia" och medlem i styrelsen för Forum för Judiska studier, Uppsala universitet. 